Correction

\title{
Correction: Feria-Díaz et al. Recent Desalination Technologies by Hybridization and Integration with Reverse Osmosis: A Review. Water 2021, 13, 1369
}

\author{
Jhon Jairo Feria-Díaz ${ }^{1,2} \mathbb{D}$, Felipe Correa-Mahecha ${ }^{3}(\mathbb{D})$, María Cristina López-Méndez ${ }^{1, *(\mathbb{D})}$, \\ Juan Pablo Rodríguez-Miranda ${ }^{4}$ and Jesús Barrera-Rojas 5
}

Citation: Feria-Díaz, J.J.;

Correa-Mahecha, F.; López-Méndez, M.C.; Rodríguez-Miranda, J.P.; Barrera-Rojas, J. Correction: Feria-Díaz et al. Recent Desalination Technologies by Hybridization and Integration with Reverse Osmosis: A Review. Water 2021, 13, 1369. Water 2021, 13, 3199. https://doi.org/ 10.3390/w13223199

Received: 20 October 2021 Accepted: 26 October 2021 Published: 12 November 2021

Publisher's Note: MDPI stays neutral with regard to jurisdictional claims in published maps and institutional affiliations.

Copyright: (c) 2021 by the authors. Licensee MDPI, Basel, Switzerland. This article is an open access article distributed under the terms and conditions of the Creative Commons Attribution (CC BY) license (https:// creativecommons.org/licenses/by/ $4.0 /)$.
1 División de Estudios Posgrado e Investigación, Tecnológico Nacional de México/Instituto Tecnológico Superior de Misantla, Misantla 93821, Mexico; jhon.feria@unisucre.edu.co

2 Facultad de Ingeniería, Universidad de Sucre, Sincelejo 700001, Colombia

3 Facultad de Ingeniería, Fundación Universidad de América, Bogotá 111321, Colombia; felipe.correa@profesores.uamerica.edu.co

4 Facultad del Medio Ambiente y Recursos Naturales, Universidad Distrital Francisco José de Caldas, Bogotá 110321, Colombia; jprodriguezm@udistrital.edu.co

5 Departamento de Energía, Universidad Autónoma Metropolitana/Unidad Azcapotzalco, Ciudad de México 02200, Mexico; jbr@azc.uam.mx

* Correspondence: mclopezm@itsm.edu.mx

In the original article [1], the reference Kurupath et al. (2021) [24] was incorrectly cited in the Figure 1 caption, and Soliman et al. (2021) [9] was incorrectly cited in the Figure 3 caption. The correct citation, Skuse et al. (2021) [27], has been inserted in the captions of Figures 1 and 3, which now read:

Figure 1. Membrane distillation operation with an air-gap configuration. Reprinted from Ref. [27].

Figure 3. Spiral wound membrane and driving force principles (inset) of RO. Reprinted from Ref. [27].

The authors apologize for any inconvenience caused and state that the scientific conclusions are unaffected. The original article has been updated.

\section{Reference}

1. Feria-Díaz, J.J.; Correa-Mahecha, F.; López-Méndez, M.C.; Rodríguez-Miranda, J.P.; BarreraRojas, J. Recent Desalination Technologies by Hybridization and Integration with Reverse Osmosis: A Review. Water 2021, 13, 1369. [CrossRef] 